\title{
Evaluation of corn cultivars harvested at two cutting heights for ensilage
}

\author{
Hamilton Caetano ${ }^{1}$, Mauro Dal Secco de Oliveira ${ }^{2}$, José Esler de Freitas Júnior ${ }^{3}$, Aníbal \\ Coutinho do Rêgo ${ }^{3}$, Francisco Palma Rennó ${ }^{4}$, Marina Vieira de Carvalho ${ }^{4}$
}

\footnotetext{
${ }^{1}$ Departamento de Medicina Veterinária da Universidade Estadual Paulista - UNESP/FMVA, Araçatuba, SP

2 Departamento de Zootecnia da Universidade Estadual Paulista - UNESP/FCAV, Jaboticabal, SP.

${ }^{3}$ Curso de Doutorado do Departamento de Zootecnia da Universidade Estadual Paulista - UNESP/FCAV, Jaboticabal, SP.

${ }^{4}$ Departamento de Nutrição e Produção Animal da Faculdade de Medicina Veterinária e Zootecnia da Universidade de São Paulo - FMVZ/USP.
}

ABSTRACT - The objective of this study was to evaluate the agronomic characteristics, bromatological-chemical composition and digestibility of 11 corn cultivars (Zea mays) harvested at two cutting heights. Cultivars D 766, D 657, D 1000, P 3021, P 3041, C 805, C 333, AG 5011, FO 01, CO 9621 and BR 205 were evaluated when they were harvested $5 \mathrm{~cm}$ above ground (low) and $5 \mathrm{~cm}$ below the insertion of the first ear (high). The experiment was designed as random blocks, with three replicates, arranged in an $11 \times 2$ factorial scheme. Cultivars presented similar productions of forage dry matter and grains. Percentages of stalk, leaf, straw, cob and kernel fractions were different among cultivars, as well as dry matter content of the whole plant at harvest. Considering the whole plant, only the contents of gross energy, nitrogen in neutral detergent fiber, and in vitro neutral and acid detergent fiber digestibility did not differ among cultivars. Increase on the cutting height improved forage quality due to the reduction of stalk and leaf fractions and contents of cell wall constituents.

Key Words: digestibility, neutral detergent fiber, plant fractions, productivity, plant fractions, water soluble carbohydrates

\section{Avaliação de cultivares de milho colhido em duas alturas de corte para ensilagem}

RESUMO - Objetivou-se neste estudo avaliar as características agronômicas, a composição químico-bromatológica e a digestibilidade de 11 cultivares de milho (Zea mays) colhido em duas alturas de corte. As cultivares D 766, D 657, D 1000, P 3021, P 3041, C 805, C 333, AG 5011, FO 01, CO 9621 e BR 205 foram avaliadas quando colhidas 5 cm acima do solo (baixa) e $5 \mathrm{~cm}$ abaixo da inserção da primeira espiga (alta). O experimento foi delineado como blocos casualizados, com três repetições, arranjados em esquema fatorial $11 \times 2$. Os cultivares apresentaram produções semelhantes de matéria seca de forragem e de grãos. As porcentagens das frações colmo, folha, palha, sabugo e grão diferiram entre os cultivares, assim como os teores de matéria seca da planta inteira no momento da colheita. Considerando a planta inteira, apenas os teores de energia bruta, nitrogênio da fração fibra em detergente neutro e a digestibilidade in vitro da fibra em detergente neutro e detergente ácido não diferiram entre os cultivares. O aumento da altura de corte melhorou a qualidade da forragem, devido à redução das frações colmo e folha e dos teores dos constituintes da parede celular.

Palavras-chave: carboidratos solúveis, digestibilidade, fibra em detergente neutro, frações da planta, poder tampão, produtividade

\section{Introduction}

In order to produce high quality whole-plant corn silage, several technical recommendations should be observed, such as the proper of maturity stage and characteristics of plant components at harvest, which result in increased nutritional value and reduced production costs (Ferreira, 1990).

According to Demarquilly (1994), the optimum stage for harvesting the whole-plant corn, described in literature, is at the maximum dry matter (DM) yield per hectare, which occurs when the corn kernel is at the dent stage (33 to $35 \%$ dry matter).
However, in order to evaluate the DM production of the corn plant, agronomical conditions, such as planting density, cutting height and DM content of the whole corn plant components, should be considered. By considering this, Wu and Roth (2005) gathered data from 11 studies utilizing corn silage harvested at two cutting heights, high and low. The authors observed that cutting height of $50 \mathrm{~cm}$ above ground, when compared to the common cutting height utilized (17 cm above ground), increased crude protein (CP) and net energy percentage, in addition to neutral detergent fiber (NDF) digestibility, therefore enhancing yield of the dairy cow milk per ton of silage. 
According to Hunter et al. (1991), the importance of kernels, as the main factor responsible for the whole-plant corn silage quality is questionable, inasmuch as there is genotypic variation in fiber quality of the plant, expressed in terms of DM intake and forage digestibility. These values do not depend on the proportion of grains in the whole corn plant DM, indicating that the forage portion significantly contributes to the overall silage quality. This confirms that the quality of the forage produced may determine several advantages regarding to intake, particularly for efficiency of nutrient use, which is intensified by the higher silage digestibility.

Moreover, variations on harvest conditions may influence the fermentation pattern during the ensiling process, causing losses in the roughage nutritional value, which besides reducing animal performance, may promote economic losses as well.

Accordingly, the objective of this work was to evaluate the agronomic characteristics, the chemical-bromathological composition and the digestibility of corn cultivars harvested in two cutting heights, as well as their respective wholeplant silages.

\section{Material and Methods}

This study was conducted in the experimental area of the Fazenda de Ensino, Pesquisa e Produção da Faculdade de Ciências Agrárias e Veterinária (FCAV) - UNESP,

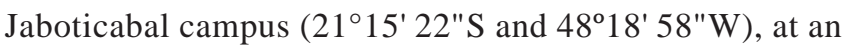
average altitude of $595 \mathrm{~m}$.

Eleven corn cultivars (D 766, D 657, D 1000, P 3021, P 3041, C 805, C 333, AG 5011, FO 01, CO 9621 and BR 205) were harvested when, by visual evaluation, the milk-line of the central ear kernels was at approximately 2/3 of the kernel. At that time, harvesting was done at two cutting heights: low ( $5 \mathrm{~cm}$ above ground) and high ( $5 \mathrm{~cm}$ below insertion of the first ear).

The experiment was designed as randomized blocks (three blocks), in an $11 \times 2$ factorial arrangement ( 11 cultivars and two cutting heights). However, because cutting height does not interfere in the chemical characteristics of the straw, cob and kernel fractions, and because height of the first ear was determined only in low cut plants, these variables were analyzed according to the randomized block design with two replicates per block and 11 corn cultivars, irrespective to the cutting heights.

The climate in the experimetnal area is classified as Cwa climate, according to the Köppen climate classification, which can be described as subtropical with a well defined dry season during winter (April to September), and a rainy season during summer (October to March). The average annual precipitation was $1,400 \mathrm{~mm}$, and the mean annual temperature is $22^{\circ} \mathrm{C}$. The soil is classified as typical eutroferric Red Latosol (Andreoli \& Centurion, 1999), with a 0 to $20 \mathrm{~cm}$ layer of argillaceous texture.

Soil was conventionally prepared with deep moldboard plowing $(30 \mathrm{~cm})$, followed by two harrow plowings immediately before sowing, and plots were composed by six $5 \mathrm{~m}$ long rows at $0.9 \mathrm{~m}$ row spacing, totalizing an area of $27 \mathrm{~m}^{2}$. Ten seeds per meter, two by two, spaced by $20 \mathrm{~cm}$ in a row, were hand sown over fertilized furrows, with the aid of a jab planter. After emergence, the number of plants was reduced to five plants per linear meter, by manual thinning, in order to obtain a final population of 55,000 plants per hectare.

Fertilization was carried out in two periods. At sowing, before planting, the fertilizer was placed in furrows, with a row planter regulated for $90 \mathrm{~cm}$ row spacing. At this time, $300 \mathrm{~kg}$ per hectare of the formula 4:30:16+Zn (3\%) were utilized, totaling $12 \mathrm{~kg}$ of $\mathrm{N}, 90 \mathrm{~kg}$ of $\mathrm{P}_{2} \mathrm{O}_{5}, 48 \mathrm{~kg}$ of $\mathrm{K}_{2} \mathrm{O}$ and $9 \mathrm{~kg}$ of $\mathrm{Zn}$ per hectare. For the second fertilization, about 25 days after emergence of the corn plants, $150 \mathrm{~kg}$ urea per hectare (67.5 kg N per hectare) was used. Then, 15 days after emergence, the presence of fall armyworms was controlled with $1.5 \mathrm{~kg}$ Sevin 850 PM per hectare.

Percentages of crude protein (CP), ether extract (EE), ash, neutral detergent fiber (NDF), acid detergent fiber $(\mathrm{ADF})$, nitrogen in acid detergent fiber (N-ADF) and cellulose were determined in whole corn plant, plant components (stalk, leaf, straw, cob and kernel) and silage samples whereas nitrogen in neutral detergent fiber (N-NDF) was determined only in whole corn plant samples, according to Silva (1998). Cellulose was determined by lignin oxidation with potassium permanganate, whereas lignin was considered as the difference between ADF and cellulose concentrations. Hemicellulose, in turn, was determined as the difference between NDF and ADF concentrations.

Antifoam agent was not used for the NDF and ADF determinations neither was sodium sulfite used for the NDF determination. All samples containing starch, namely whole corn plants and kernels, it was added $0.2 \mathrm{ml}$ amylase PA. Cellulose values presented in this study refer to cellulose plus insoluble minerals, once that inasmuch as residues from cellulose determination were not ashed.

Nitrogen $(\mathrm{N})$ was determined by using the semimicrokjeldahl method, phosphorus (P) by colorimetry with vanadate-molibdate solution, potassium $(\mathrm{K})$ by flame photometry, calcium $(\mathrm{Ca})$ and magnesium $(\mathrm{Mg})$ by atomic 
absorption spectrophotometry, and sulfur (S) by the turbidimetric barium sulfate method.

Gross energy (GE) was determined in whole corn plant samples, with a semi-automatic Parr calorimetric bomb, model 1281.

Dry matter, $\mathrm{CP}, \mathrm{NDF}$ and ADF in vitro digestibility (IVDMD, IVCPD, IVNDFD and IVADFD, respectively) in silage samples were determined through a digestibility assay in an Ankom ${ }^{\circledR}$ Ruminal Fermenter ("Daisy-II Fermenter”). For these analyses, $0.25 \mathrm{~g}$ of sample was weighed in F57 digestion bags, previously washed in acetone, then they were dried in air forced oven at $65^{\circ} \mathrm{C}$ and weighed. Bags for obtainment of residues for CP determination, however, received approximately $0.4 \mathrm{~g}$ of sample. After being sealed, bags were put into the digestion container (25 bags each) with $1,600 \mathrm{ml}$ pre-heated $\left(39^{\circ} \mathrm{C}\right)$ buffer, which was composed of a 5:1 mixture of a solution A $(10 \mathrm{~g} / \mathrm{L}$ $\mathrm{KH}_{2} \mathrm{PO}_{4} ; 0.5 \mathrm{~g} / \mathrm{L} \mathrm{MgSO}_{4} .7 \mathrm{H}_{2} \mathrm{O} ; 0.5 \mathrm{~g} / \mathrm{L} \mathrm{NaCl} ; 0.1 \mathrm{~g} / \mathrm{L} \mathrm{CaCl}_{2}$ and $0.5 \mathrm{~g} / \mathrm{L}$ urea-degree reactive) and a solution $\mathrm{B}(15 \mathrm{~g} / \mathrm{L}$ $\mathrm{Na}_{2} \mathrm{CO}_{3}$ and $1.0 \mathrm{~g} / \mathrm{L} \mathrm{Na}_{2} \mathrm{~S} .9 \mathrm{H}_{2} \mathrm{O}$ ). After that, $400 \mathrm{~mL}$ of ruminal fluid inoculum was added into each recipient.

The ruminal fluid inoculum was obtained from a rumen cannulated Holstein steer that was adapted for 15 days in feedlot, receiving about $25 \mathrm{~kg}$ corn silage, $2 \mathrm{~kg}$ concentrate and water ad libitum. During the ruminal fluid collection period, the steer received the same diet.
For the in vitro DM digestibility determination, samples were incubated for 48 hours, followed by $8 \mathrm{~g}$ pepsin and $40 \mathrm{~mL} \mathrm{HCl} 6 \mathrm{~N}$ addition for another 24 hours under heating. Pepsin and $\mathrm{HCl}$ were added only in samples of kernel and leaf fraction. For in vitro NDF and ADF digestibility determination, only the bags with whole corn plant samples were taken to the Ankom ${ }^{\circledR}$ fiber analyzer equipment, after being dried and weighed. The in vitro $\mathrm{CP}$ digestibility coefficient was obtained after $\mathrm{CP}$ determination from whole corn plant samples residues present in the bags incubated for 48 hours, after being dried in forced air oven at $65^{\circ} \mathrm{C}$. In order to calculate the in vitro true DM digestibility coefficient, the indigestible DM was considered as only the NDF residue obtained from the determination of the in vitro NDF digestibility coefficient.

Results were submitted to analysis of variance and means were compared by the Tukey test at 5\% probability. Statistical analyses were performed in the SAS (1999) program, and all variables were tested for normality of residues. Blocks were used for local control.

\section{Results and Discussion}

There were no differences $(\mathrm{P}>0.05)$ in forage $\mathrm{DM}$ production, grain DM per hectare production and grain production between the different cultivars (Table 1). The

Table 1 - Dry matter production of the whole corn plant harvested at high and low cutting heights

\begin{tabular}{|c|c|c|c|c|}
\hline & \multicolumn{2}{|c|}{ Dry matter production (t/ha) } & \multirow[t]{2}{*}{ Kernels dry matter production } & \multirow[t]{2}{*}{$1^{\text {st }}$ ear $(\mathrm{cm})$} \\
\hline & Low cutting height & High cutting heigh & & \\
\hline \multicolumn{5}{|l|}{ Cultivar } \\
\hline Dina 766 & $14.24 \mathrm{a}$ & $10.21 \mathrm{a}$ & $4.89 a$ & $76.73 \mathrm{~cd}$ \\
\hline Dina 657 & $15.16 a$ & $11.35 a$ & $4.16 a$ & $100.53 a b$ \\
\hline Dina 1000 & $14.39 a$ & $10.18 \mathrm{a}$ & $4.05 a$ & 80.67bcd \\
\hline P 3021 & $15.01 \mathrm{a}$ & $10.07 \mathrm{a}$ & $4.48 a$ & $81.87 \mathrm{bcd}$ \\
\hline P 3041 & $16.84 \mathrm{a}$ & $10.05 a$ & $5.07 a$ & $93.00 \mathrm{abc}$ \\
\hline C 805 & $14.09 a$ & $11.88 \mathrm{a}$ & $5.08 a$ & $69.20 \mathrm{~d}$ \\
\hline C 333 & $15.30 \mathrm{a}$ & $10.41 \mathrm{a}$ & $4.60 \mathrm{a}$ & $71.20 \mathrm{~cd}$ \\
\hline AG 5011 & $14.12 \mathrm{a}$ & $10.26 a$ & $3.87 a$ & $75.60 \mathrm{~cd}$ \\
\hline FO 01 & $13.40 \mathrm{a}$ & $10.45 a$ & $3.44 \mathrm{a}$ & $113.07 \mathrm{a}$ \\
\hline Dina co 9621 & $14.96 a$ & $11.89 a$ & 4.63a & $101.53 a b$ \\
\hline BR 205 & $14.09 \mathrm{a}$ & $13.50 \mathrm{a}$ & $4.23 \mathrm{a}$ & 82.60bcd \\
\hline \multicolumn{5}{|l|}{ Cutting height } \\
\hline High & $14.69 \mathrm{a}$ & - & - & - \\
\hline Low & - & $10.93 b$ & - & - \\
\hline \multicolumn{5}{|c|}{ Significance level } \\
\hline Cultivar & 0.6410 & 0.6410 & 0.0300 & 0.0001 \\
\hline Cutting height & 0.0001 & 0.0001 & - & - \\
\hline Cultivar $\times$ cutting height & 0.2507 & 0.2507 & - & - \\
\hline Coefficient of variation (\%) & 13.34 & 13.34 & 19.22 & 9.22 \\
\hline
\end{tabular}

\footnotetext{
Means, in a column, followed by the same letters do not differ $(\mathrm{P}>0.05)$ by Tukey test.
} 
first ear insertion height was higher $(\mathrm{P}<0.05)$ in cultivars Dina $657(100.53 \mathrm{~cm})$, FO $01(113.07 \mathrm{~cm})$ and Dina Co 9621 (101.53 cm), compared with cultivars C 805, C 333 and AG 5011. These results are in agreement with Beleze et al. (2003), who reported an average height of first ear insertion of $122.0 \mathrm{~cm}$, for minimal and maximal observed heights of 100 . $0 \mathrm{~cm}$ and $134.0 \mathrm{~cm}$. When evaluating silages of the simple forage corn hybrid P-30S40, Neumann et al. (2007) observed mean heights of the first ear of $142 \mathrm{~cm}$. However, kernel DM production $(\mathrm{KDMP})$ was greater $(\mathrm{P}<0.05)$ in the high cutting height (Table 2), probably because harvest was realized at an earlier stage of development, when the low cutting height was desired, therefore, there was no time for sufficient DM accumulation in the kernels (Afuakwa \& Crookston, 1984; Hunter et al., 1991; Beleze et al., 2003).

Considering the forage DM production per hectare, there was no interaction between cultivars and cutting height $(\mathrm{P}=0.2507)$. Regarded to that, in addition to the fact that mean production of each cultivar harvested at the two cutting heights do not have any practical meaning, and considering that DM production is a very important variable in corn evaluation for silage production, it was chosen to present the results of high and low cutting height groups separately. However, the numerical difference (1.64 t/ha) between cultivar C805, which had the greatest production (5.08 t/ha), and cultivar FO 01, which had the lowest production (3.44 t/ha), is very high and should be considered. Besides, the analysis of variance indicated that kernel production should differ among cultivars, at 3\% probability, which was not detected by the Tukey test ( $\mathrm{P}>0.05)$ (Table 3).

During the final third of the experimental period, rain scarcity could have affected grain filling, resulting in reduced average kernel production (4.41 t DM/ha), mostly when the good forage DM production of plants harvested at low cutting height (14.69 t/ha) (Table 1) is considered. Beleze et al. (2003) reported a mean kernel production of approximately 7.0 t/ha for corn hybrids P32R21; P30R07; P304; P30F33 and P30F80, higher than the results presented in this study. In the same way, Mello et al. (2005) also reported kernel production values of about $8.71 \mathrm{t} / \mathrm{ha}$, when evaluating six corn hybrids for silage production.

Higher kernel production (6.27 t DM/ha) with lower forage DM production per hectare (13.63 t) was reported by Henrique et al. (1994) and Pereira et al. (1993). It should be mentioned that, for a constant total forage DM production per hectare, the effects of increasing cutting height on silage quality improvement will be smaller when kernel production per hectare is lower.

Cutting height, in turn, significantly affected forage DM production per hectare $(\mathrm{P}<0.05)$ (Table 1$)$, which was reduced in $25.60 \%$ when mean cutting height increased from five to about $80 \mathrm{~cm}$. Similarly, Lauer (1998) observed a 15\% reduction of forage production per area, when cutting

Table 2 - Component fractions percentage of the whole corn plant harvested at high and low cutting heights

\begin{tabular}{|c|c|c|c|c|c|c|}
\hline & Leaf & Stalk & Cob & Straw & Kernel & Ear \\
\hline & ------ & -------- & -------- & $M$ of the plan & 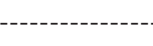 & -------- \\
\hline \multicolumn{7}{|l|}{ Cultivar } \\
\hline Dina 766 & $11.39 \mathrm{e}$ & $19.02 c$ & $12.64 \mathrm{bcd}$ & 16.87bcde & $40.08 a$ & $69.59 a$ \\
\hline Dina 657 & 14.07abc & $21.84 \mathrm{bc}$ & 11.84 cde & $20.30 \mathrm{abc}$ & 31.96bcd & $64.10 \mathrm{bcd}$ \\
\hline Dina 1000 & 13.82abc & 22.54abc & 12.01cde & 18.17bcde & 33.46abcd & 63.64bcd \\
\hline P 3021 & $12.01 \mathrm{cde}$ & $21.45 b c$ & 12.05 cde & 18.01bcde & 36.50abc & $66.55 a b c$ \\
\hline P 3041 & $11.42 \mathrm{e}$ & $21.98 b c$ & 13.33bc & $14.64 \mathrm{e}$ & $38.62 \mathrm{ab}$ & $66.60 \mathrm{abc}$ \\
\hline C 805 & $10.68 \mathrm{e}$ & $20.67 \mathrm{bc}$ & $14.10 \mathrm{~b}$ & $15.02 \mathrm{de}$ & 39.53a & $68.65 \mathrm{ab}$ \\
\hline C 333 & 11.65 de & $20.63 \mathrm{bc}$ & 11.99cde & 19.17abcd & 36.58abc & 67.73abc \\
\hline AG 5011 & 13.55abcd & 21.25 bc & $16.48 \mathrm{a}$ & 16.39cde & 32.33bcd & $65.20 \mathrm{abc}$ \\
\hline FO 01 & $14.87 \mathrm{a}$ & $26.35 a$ & 8.09f & 20.98ab & 29.72d & $58.78 \mathrm{~d}$ \\
\hline Dina co 9621 & $14.12 \mathrm{ab}$ & $23.35 \mathrm{ab}$ & $11.04 \mathrm{de}$ & 16.72 cde & $34.77 \mathrm{abcd}$ & $62.53 \mathrm{~cd}$ \\
\hline BR 205 & 12.47bcde & $23.18 \mathrm{ab}$ & $10.22 \mathrm{e}$ & $23.24 \mathrm{a}$ & 30.89cd & $64.35 \mathrm{abc}$ \\
\hline \multicolumn{7}{|l|}{ Cutting height } \\
\hline Low & $13.69 a$ & $28.09 a$ & $10.69 b$ & $16.65 b$ & $30.89 b$ & $58.22 b$ \\
\hline \multirow[t]{2}{*}{ High } & $11.77 b$ & $15.95 b$ & $13.63 a$ & $19.63 a$ & $39.01 \mathrm{a}$ & $72.27 \mathrm{a}$ \\
\hline & \multicolumn{6}{|c|}{ Significance level } \\
\hline Cultivar & 0.0001 & 0.0001 & 0.0001 & 0.0001 & 0.0001 & 0.0001 \\
\hline Cutting height & 0.0001 & 0.0001 & 0.0001 & 0.0001 & 0.0001 & 0.0001 \\
\hline Cultivar $\times$ Cutting height & 0.7835 & 0.0823 & 0.4710 & 0.5878 & 0.8630 & 0.1844 \\
\hline Coefficient of variation (\%) & 8.44 & 9.36 & 8.08 & 11.75 & 9.76 & 4.18 \\
\hline
\end{tabular}

Means, in a column, followed by the same letters do not differ $(\mathrm{P}>0.05)$ by Tukey test. 
Table 3 - Bromathological composition of whole corn plants harvested in two cutting heights

\begin{tabular}{|c|c|c|c|c|c|c|c|}
\hline & $\begin{array}{l}\text { Buffering capacity } \\
(\mathrm{mEq} / 100 \mathrm{~g} \mathrm{DM})\end{array}$ & $\begin{array}{l}\text { Water soluble } \\
\text { carbohidrates }\end{array}$ & $\begin{array}{c}\text { Dry } \\
\text { matter }\end{array}$ & Ash & $\begin{array}{l}\text { Ether } \\
\text { extract }\end{array}$ & $\begin{array}{c}\text { Crude } \\
\text { protein }\end{array}$ & $\begin{array}{l}\text { Gross energy } \\
\text { (Mcal/kg DM) }\end{array}$ \\
\hline & & & 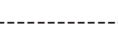 & $\%$ in DI & & & \\
\hline \multicolumn{8}{|l|}{ Cultivar } \\
\hline Dina 766 & $16.16 \mathrm{ab}$ & $12.22 \mathrm{ab}$ & $31.85 a b$ & $3.11 \mathrm{ab}$ & $2.50 \mathrm{a}$ & $8.52 \mathrm{ab}$ & $4.15 a$ \\
\hline Dina 657 & $17.32 \mathrm{ab}$ & $14.30 \mathrm{ab}$ & $31.53 a b$ & 2.93b & 1.98abc & $8.21 \mathrm{abc}$ & $4.18 \mathrm{a}$ \\
\hline Dina 1000 & $17.38 \mathrm{ab}$ & $16.12 \mathrm{a}$ & $28.17 b$ & $3.21 \mathrm{ab}$ & $2.26 \mathrm{abc}$ & 8.17abc & $4.14 \mathrm{a}$ \\
\hline P 3021 & $14.45 b$ & $14.46 \mathrm{a}$ & $32.01 \mathrm{ab}$ & $2.68 b$ & $2.25 \mathrm{abc}$ & $7.57 \mathrm{c}$ & $4.17 \mathrm{a}$ \\
\hline P 3041 & $17.45 a b$ & $13.01 \mathrm{ab}$ & $31.45 \mathrm{ab}$ & $3.30 \mathrm{ab}$ & $2.30 \mathrm{abc}$ & $7.77 \mathrm{bc}$ & 4.19a \\
\hline C 805 & $14.48 b$ & $14.21 \mathrm{ab}$ & $34.16 a$ & $2.74 b$ & 2.23abc & $7.52 c$ & $4.14 \mathrm{a}$ \\
\hline C 333 & $14.60 \mathrm{~b}$ & $10.12 b$ & $33.88 a$ & $3.10 \mathrm{ab}$ & $2.49 \mathrm{ab}$ & 8.29abc & $4.16 a$ \\
\hline AG 5011 & $18.25 \mathrm{a}$ & $14.00 \mathrm{ab}$ & $29.34 b$ & 3.93a & 2.03abc & $9.04 \mathrm{a}$ & $4.18 \mathrm{a}$ \\
\hline FO 01 & $19.24 \mathrm{a}$ & $13.59 \mathrm{ab}$ & $29.41 b$ & $3.31 \mathrm{ab}$ & $1.81 \mathrm{bc}$ & $8.97 \mathrm{a}$ & $4.18 \mathrm{a}$ \\
\hline Dina co 9621 & $16.75 a b$ & $13.89 a b$ & $31.39 a b$ & $3.27 \mathrm{ab}$ & 2.08abc & $8.81 \mathrm{a}$ & $4.19 a$ \\
\hline BR 205 & $17.27 \mathrm{ab}$ & $13.25 a b$ & $31.21 \mathrm{ab}$ & $3.09 \mathrm{ab}$ & $1.68 c$ & $7.83 \mathrm{bc}$ & 4.13a \\
\hline \multicolumn{8}{|l|}{ Cutting height } \\
\hline Low & $17.79 a$ & $14.34 \mathrm{a}$ & $29.58 b$ & $3.45 a$ & $2.10 \mathrm{a}$ & $8.16 \mathrm{a}$ & $4.16 \mathrm{a}$ \\
\hline High & $15.55 b$ & $12.74 b$ & $33.04 \mathrm{a}$ & $2.85 b$ & $2.19 \mathrm{a}$ & $8.33 a$ & $4.17 \mathrm{a}$ \\
\hline Variation source & \multicolumn{7}{|c|}{ Significance level } \\
\hline Cultivar & 0.0001 & 0.0060 & 0.0001 & 0.0126 & 0.0034 & 0.0001 & 0.2529 \\
\hline Cutting height & 0.0001 & 0.0055 & 0.0001 & 0.0001 & 0.2645 & 0.1381 & 0.5141 \\
\hline Cultivar $\times$ height & 0.0939 & 0.4993 & 0.9350 & 0.1521 & 0.3044 & 0.8722 & 0.1044 \\
\hline Coefficient of variation (\%) & 10.34 & 15.69 & 6.42 & 15.96 & 16.39 & 5.63 & 1.01 \\
\hline
\end{tabular}

Means, in a column, followed by the same letters do not differ $(\mathrm{P}>0.05)$ by Tukey test.

height was increased from 15 to $45 \mathrm{~cm}$, corresponding to an $865 \mathrm{~kg} \mathrm{DM} / \mathrm{ha}$ decrease per $15 \mathrm{~cm}$ of increase in cutting height. In the present study, this value corresponded to $752 \mathrm{~kg}$ DM, for the same difference in cutting height.

Generally, cultivars FO 01, Dina 657, Dina 1000, had greater proportion of leaves and stalks, and lower proportion of cobs and kernels participating in the DM of the whole plant, resulting in ears smaller than those of cultivars Dina 766 e C 805, P 3021, P 3041, C 333, BR 205, which had lower percentage of leaves and stalks, and greater percentage of kernels and ears. This result can be explained by the forage characteristic of the former cultivars, in which, as reported by Penati (1995), the extremely early cycle probably was the cause of the greater kernel percentage observed. Similarly, Zopollatto et al. (2009) evaluated the morphological composition of six corn cultivars (CO 32; AG 5011; P 3041; DKB-333B; AG 1051 and Z 8550) and observed a mean proportion of leaf and stalk of $23 \%$ and $25 \%$, respectively, about 85 days after sowing.

The percentage of kernels is the main cause of high DM productivity of the whole corn plant per area, high nutritive value for ruminants, and adequate DM percentage that produces adequate fermentation pattern and reduces effluent losses during the ensiling process. Therefore, kernel percentage has been the most utilized criteria for choosing corn cultivars for silage production (Hunter, 1991; Penati, 1995).
Cultivars Dina 766, Dina 657, Dina 1000, P 3041, FO 01, AG 5011, Dina co 9621 and BR 205 had greater buffering capacity $(\mathrm{P}<0.05)$, than cultivars $\mathrm{P} 3021$, C 805 e C 333 (Table 3). Moreover, the mean values observed in the low cutting height group are very similar to those reported by McDonald et al. (1991) for corn crops, $17 \mathrm{mEq} \mathrm{HCl} / 100 \mathrm{~g}$ DM; and by Lavezzo et al. (1997) for corn harvested at the kernel milk stage, which was $17.25 \mathrm{mEq} \mathrm{HCl} / 100 \mathrm{~g}$ DM.

The buffering capacity of whole corn plants harvested at the high cutting height was significantly reduced $(\mathrm{P}<0.05)$, when compared to plants harvested at the low cutting height. Cultivars P 3021, C 805 and C 333 had the lowest buffering capacity $(\mathrm{P}<0.05)$, compared to cultivars AG 5011 and FO 01. Cutting height also altered the level of water soluble carbohydrates, which was significantly reduced $(\mathrm{P}<0.05)$ in plants harvested at the high cutting height. However, plants cut lower had a mean water soluble carbohydrates level, in DM basis, close to $14.5 \%$, which was reported by McDonald et al. (1991) for a corn crop that produced well preserved silage. Water soluble carbohydrates levels differ among cultivars $(\mathrm{P}<0.05)$, however.

For DM levels, cultivars AG 5011, Dina 1000 and FO 01 showed values lower than cultivars C 805 and C 333. Cutting height also affected the plant DM content. So, the greater percentage of ears and the lower percentage of the vegetative fraction (leaf and stalk) were causes of the higher DM levels of plants harvested at the high cutting height. 
Ash, ether extract (EE) and crude protein (CP), determined in whole corn plant samples, differed among cultivars ( $\mathrm{P}<0.05$ ) (Table 3). Cultivars AG 5011, FO 01 and Dina CO 9621, recommended for silage production, had higher CP levels, compared to cultivars C 805 and $P$ 3021. There was no difference among cultivars for gross energy level (GE) ( $P>0.05)$. Cutting height did not alter the EE, CP and GE content of the plants $(\mathrm{P}>0.05)$.
Cultivars Dina 657 and FO 01 had higher $(\mathrm{P}<0.05)$ NDF levels, compared with cultivars Dina 766, P 3021 and P 3041 (Table 4). Similar behavior was observed in hemicellulose level, except for cultivar P 3041, which did not differ from cultivar FO 01. High cutting height produced lower mean values of NDF and hemicellulose than low cutting height $(\mathrm{P}<0.05)$ did, which could have been caused by the reduction of the vegetative fraction and increase in kernel production in the whole plant DM.

Table 4 - Bromathological composition, in \% of dry matter, of the whole corn plant cell wall in two cutting heights

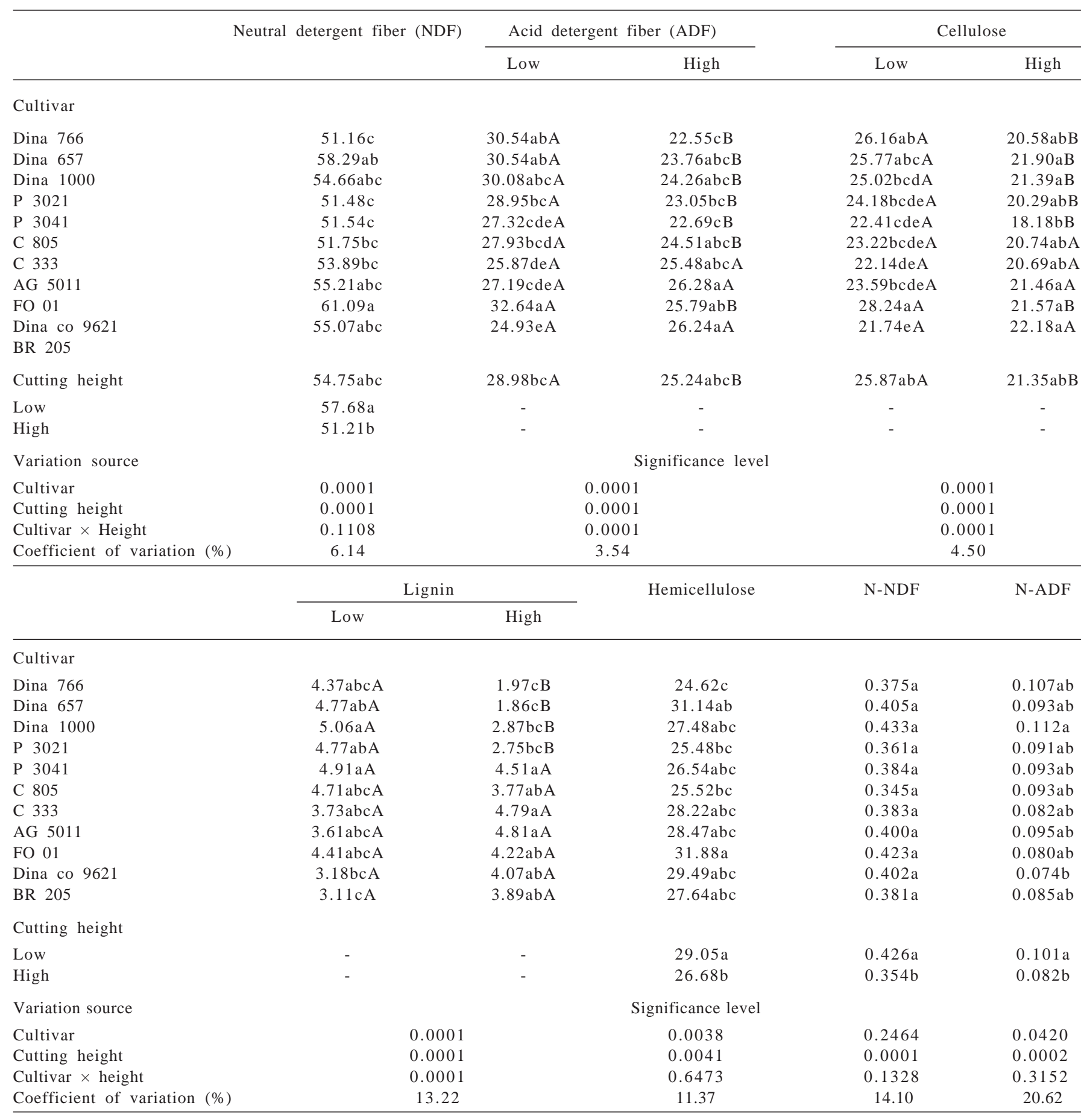

Means followed by the same capital letters (line) and lower case letters (column) do not differ ( $\mathrm{P}>0.05)$ by the Tukey test. 
Table 5 - Digestibility coefficients of the whole corn plants harvested at high and low cutting heights

\begin{tabular}{|c|c|c|c|c|c|}
\hline & $\begin{array}{c}\text { True in vitro DM } \\
\text { digestibility }\end{array}$ & $\begin{array}{l}\text { In vitro DM } \\
\text { digestibility }\end{array}$ & $\begin{array}{c}\text { In vitro NDF } \\
\text { digestibility }\end{array}$ & $\begin{array}{l}\text { In vitro ADF } \\
\text { digestibility }\end{array}$ & $\begin{array}{l}\text { In vitro } \mathrm{CP} \\
\text { digestibility }\end{array}$ \\
\hline \multicolumn{6}{|l|}{ Cultivar } \\
\hline Dina 766 & $71.21 \mathrm{a}$ & $63.85 \mathrm{a}$ & $44.32 \mathrm{a}$ & $44.12 \mathrm{a}$ & $64.09 \mathrm{a}$ \\
\hline Dina 657 & $67.06 \mathrm{ab}$ & $60.75 \mathrm{ab}$ & $43.28 \mathrm{a}$ & $36.02 \mathrm{a}$ & $60.32 \mathrm{ab}$ \\
\hline Dina 1000 & $69.00 \mathrm{ab}$ & $62.82 \mathrm{ab}$ & $43.53 a$ & $40.78 a$ & $60.90 \mathrm{ab}$ \\
\hline C 805 & $71.10 \mathrm{a}$ & 63.98a & $43.89 a$ & $41.52 \mathrm{a}$ & $59.95 a b$ \\
\hline С 333 & $66.39 a b$ & $59.38 \mathrm{ab}$ & $37.56 a$ & $29.32 \mathrm{a}$ & $52.13 b$ \\
\hline AG 5011 & $70.00 \mathrm{ab}$ & $61.51 \mathrm{ab}$ & $45.74 a$ & $39.82 \mathrm{a}$ & 62.53ab \\
\hline FO 01 & 61.39b & $56.67 \mathrm{~b}$ & $36.49 a$ & $28.00 \mathrm{a}$ & $60.45 a b$ \\
\hline Dina со 9621 & $65.47 \mathrm{ab}$ & $59.84 a b$ & $37.32 \mathrm{a}$ & $27.62 \mathrm{a}$ & $57.62 \mathrm{ab}$ \\
\hline BR 205 & $69.84 \mathrm{ab}$ & $64.03 \mathrm{a}$ & $45.10 \mathrm{a}$ & $41.38 \mathrm{a}$ & $60.49 a b$ \\
\hline Variation source & & & Significance level & & \\
\hline Cultivar & 0.0146 & 0.0031 & 0.1517 & 0.0378 & 0.0646 \\
\hline Cutting height & 0.0008 & 0.0016 & 0.7913 & 0.1459 & 0.5117 \\
\hline Cultivar $\times$ Cutting height & 0.6882 & 0.6688 & 0.5664 & 0.5817 & 0.5134 \\
\hline Coefficiente of variation (\%) & 6.54 & 5.19 & 16.33 & 26.88 & 8.95 \\
\hline
\end{tabular}

Means, in a column, followed by the same letters do not differ $(\mathrm{P}>0.05)$ by Tukey test.

Cell wall associated to nitrogen was evaluated by $\mathrm{N}$ concentration in NDF (N-NDF) and ADF (N-ADF) fractions. There was no difference $(\mathrm{P}>0.05)$ in $\mathrm{N}-\mathrm{NDF}$ level among cultivars, however, N-ADF in cultivar Dina 1000 was higher than in cultivar Dina co 9621, which showed the lowest $\mathrm{N}$-ADF value $(\mathrm{P}<0.05)$. But, mean $\mathrm{N}-\mathrm{ADF}$ and $\mathrm{N}-\mathrm{NDF}$ were higher in plants harvested at low cutting height, reflecting the difference observed in NDF and ADF levels. There was a significant interaction between cultivar and cutting heights, regarding to ADF, cellulose and lignin values $(\mathrm{P}<0.05)$.

Cutting height did not influence the in vitro NDF, ADF and CP digestibility coefficients (Table 5). On the other hand, in vitro dry matter digestibility and in vivo dry matter digestibility coefficients of plants harvested at high cutting height were higher than $(\mathrm{P}<0.05)$ those of plants harvested at low cutting height, confirming that variability of plant components affects the final forage digestibility. Analyzing silages from 33 corn hybrids for two consecutive years, Allen (1990) observed that the amplitude of in vitro DM (74 to $80 \%$ ) and fiber (41 to $46 \%$ ) digestibility coefficients varied very little, compared to amplitudes of ADF levels (38 to 53\%) and kernel percentage in DM (22 a 53\%). The author concluded that, besides the high variation in kernel percentage in DM, dry matter digestibility remained stable, indicating that other plant components also play an important role on the ensiled forage quality.

\section{Conclusions}

Increasing cutting height improves corn silage quality because of the reduction of stalk and leaf fractions, and because of the reduction of cell wall constituents. Cultivars Dina 766 and C 805 represent a good option for corn silage production inasmuch as they present kernel and fibrous (stalk, leaf, cob and ear) fractions of better quality. Values of the fibrous fraction, in percentage of the whole plant, together with higher total DM digestibility, result in higher quality of the ensiled material for these two cultivars.

\section{References}

AFUAKWA, J.J.; CROOKSTON, R.K. Using the kernel milk line to visually monitor rain maturity in maize. Crop Science, v.24, p.687-691, 1984.

ALLEN, M. All corn silage is not created equal. Fort Atkinson: Hord's Dairyman, 1990. 766p.

ANDREOLI, I.; CENTURION, J.F. Levantamento detalhado dos solos da Faculdade de Ciências Agrárias e Veterinárias de Jaboticabal. In: CONGRESSO BRASILEIRO DE CIÊNCIA DO SOLO, 27., 1999, Brasília. Anais... Brasília: Sociedade Brasileira de Ciência do Solo, 1999. p.32. (TO25-3 CD-ROM) (Resumo).

BELEZE, J.R.F.; ZEOULA, L.M.; CECATO, U. et al. Avaliação de cinco híbridos de milho (Zea mays, L.) em diferentes estádios de maturação. 1. Produtividade, características morfológicas e correlações. Revista Brasileira de Zootecnia, v.32, n.3, p.529-537, 2003.

DEMARQUILLY, C. Facteurs de variation de la valeur nutritive du mais ensilage. INRA. Production Animal, v.7, n.3, p.177-189, 1994. 
FERREIRA, J.J. Aspectos vegetativos da planta de milho e momento da colheita para ensilagem. Informe Agropecuário, v.14, n.164, p.47-49, 1990.

HENRIQUE, W.; PERES, R.M.; VIANA, J.L. et al. Avaliação de três híbridos de milho para produção de silagem. In: REUNIÃO ANUAL DA SOCIEDADE BRASILEIRA DE ZOOTECNIA, 31., 1994, Maringá. Anais... Maringá: SBZ, 1994. p.343.

HUNTER, J.L.; TEKRONY, D.M.; MILES, D.F. et al. Corn seed maturity indicators and their relationship to uptake of Carbon14 assimilate. Crop Science, v.31, n.5, p.1309-1313, 1991.

LAUER, J. Corn silage cutting height. [1998]. Disponível em: $<$ http://www.uwex.edu/ces/ forage/articles.htm\#silage>. Acesso em: 8/8/2009.

LAVEZZO, W.; LAVEZZO, O.E.N.M.; CAMPOS NETO, O. Estádio de desenvolvimento do milho. Efeito sobre produção, composição da planta e qualidade da silagem. Revista Brasileira de Zootecnia, v.26, n.4, p.675-682, 1997.

McDONAlD, P.; HENDERSON, A.R.; HERON, S.J.E. The biochemistry of silage. 2.ed. Marlow: Chalcombe Publications, 1991. 340p.

MELLO, R.; NÖRNBERG, J.L.; ROCHA, M.G. et al. Características produtivas e qualitativas de híbridos de milho para produção de silagem. Revista Brasileira de Milho e Sorgo, v.4, n.1, p.79-94, 2005.

NEUMANN, M.; MÜHLBACH, P.R.F.; RESTLE, J. et al. Silagem de milho (Zea mays, l.) Em diferentes alturas de corte e tamanho de partícula: produção, composição e utilização na terminação de bovinos em confinamento. Revista Brasileira de Milho e Sorgo, v.6, n.3, p.379-397, 2007.

PENATI, M.C. Relação de alguns parâmetros agronômicos e bromatológicos de híbridos de milho (Zea mays L.) com a produção, digestibilidade e teor de matéria seca na planta. 1995. 97f. Dissertação (Mestrado em Agronomia) Escola Superior de Agricultura "Luiz de Queiroz", Universidade de São Paulo, Piracicaba.

PEREIRA, O.D.; OBEID, J.A.; GOMIDE, J.A. et al. Produtividade de uma variedade de milho (Zea mays L.) e de três variedades de sorgo (Sorghum bicolor L.) e o valor nutritivo de suas silagens. Revista Brasileira de Zootecnia, v.22, n.1, p.31-38, 1993.

STATISTICAL ANALYSIS SYSTEM - SAS. SAS/STAT User's Guide. Release 8.0 Edition. Cary: SAS, 1999. 1500p.

SILVA, D.J. Análise de alimentos: Métodos químicos e biológicos. 2.ed. Viçosa, MG: UFV, 1998. 166p.

WU, Z.; ROTH, G. Considerations in managing cutting height of corn silage. College Park: Pennsylvania State University, 2005. p.3.-72. (Extension publication DAS).

ZOPOLLATTO, M.; NUSSIO, L.G.; MARI, L.J. et al. Alterações na composição morfológica em função do estádio de maturação em cultivares de milho para produção de silagem. Revista Brasileira de Zootecnia, v.38, n.3, p.452-461, 2009. 